\title{
Announcing the Second Society \& Animals Early Career Research Prize
}

Brill and Animals and Society Institute are pleased to announce the winner of the second Early Career Research Prize. The prize is awarded annually for the best article published in Society \& Animals: Journal of Human-Animal Studies. The purpose of the award is to encourage scholars to join the field and to assist them in obtaining additional exposure for their work. The winning article is announced in the journal and is made available in Open Access for no charge.

\section{Eligibility}

Eligible authors are doctoral students at the dissertation stage, students pursuing other terminal degrees (MSW, DVM, or JD), or early career scholars with no more than four years past their $\mathrm{PhD}$ or other terminal degree.

\section{Selection Process}

In December of each year, the managing editors of $S \& A$ select the article published in that year judged to make the most significant contribution to the field of Human-Animal Studies.

\section{And the Winner of the 2021 Prize Is ...}

Oliver Keane for his article entitled, Genetically engineered nonhuman animals: A global overview and research agenda (Society \& Animals, 2021, 2, 173-202).

The full text of the article is available in Open Access at Genetically Engineered Nonhuman Animals: A Global Overview and Research Agenda in: Society \& Animals Volume 29 Issue 2 (2021) (brill.com) 
Here is the abstract:

This paper suggests studies on genetically engineering nonhuman animal genes have globalized over the last 30 years. The results unveil maps that give a global overview of universities' studies into engineering animal genes, by purpose and by species, at a state scale. A network map also shows how studies on engineering animal genes are co-constituted internationally, at a state scale. Some of the more notable map findings are developed using a novel ontological approach. This ontology relates the being of an animal, a constitutive lack, to power relations. The beings of animals are trapped into serving capital through the engineering of their genes. This reconfiguration allows the ensnaring of the body in agricultural, or other, power relations. The scale of this carceral archipelago is positioned as a global risk. Life energy, by nature, resists capture. Therefore, the paper concludes that the clock is ticking on genetic scientists' Faustian bargain.

To download the full text, go to https://doi.org/10.1163/15685306-12341588. 